\title{
PENINGKATAN MOTIVASI DAN KEMAMPUAN MENGINSTALASI SISTEM OPERASI JARINGAN MELALUI METODE DISCOVERY LEARNING PADA SISWA KELAS XI-TKJ SMK NEGERI 1 SIGLI
}

\begin{abstract}
Nuraidah
ABSTRAK

Rendahnya motivasi belajar siswa dipengaruhi oleh beberapa faktor diantaranya adalah penggunaan metode pembelajaran yang kurang tepat sehingga dapat berpengaruh terhadap motivasi dan kemampuan siswa. Penelitian ini bertujuan untuk meningkatkan motivasi dan kemampuan menginstalasi sistem operasi jaringan melalui metode discovery learning pada siswa kelas XI-TKJ SMK Negeri 1 Sigli. Penelitian ini merupakan Penelitian Tindakan Kelas (PTK) dengan prosedur pelaksanaannya melalui tahapan: perencanaan, pelaksanaan, pengamatan, dan refleksi. Penelitian ini dilaksanakan pada semester ganjil tahun pelajaran 2019/2020. Subjek dalam penelitian adalah siswa kelas XI TKJ SMK Negeri 1 Sigli yang berjumlah 28 orang. Teknik pengumpulan data melalui observasi, tes dan dokumentasi. Analisis data secara deskriptif kualitatif. Hasil penelitian menunjukkan: ketuntasan hasil belajar siswa secara klasikal pada kondisi awal 46,4\%. Pada siklus I, ketuntasan siswa meningkat 14,3\% dari sebelumnya yang mencapai $60,7 \%$ sehingga ketuntasan belajar secara klasikal dikatakan tidak tuntas. Pada siklus ke II terjadi peningkatan yang signifikan yaitu meningkat $35,7 \%$ sehingga menjadi 96.4\%. Maka disimpulkan bahwa penggunaan metode discovery learning dapat meningkatkan motivasi dan kemampuan menginstalasi sistem operasi jaringan pada siswa kelas XI TKJ SMK Negeri 1 Sigli.
\end{abstract}

Kata Kunci: Motivasi, Kemampuan, Menginstalasi, dan Metode Discovery Learning. 


\section{PENDAHULUAN}

Pembelajaran adalah proses pembimbingan terhadap peserta didik melalui interaksi antar peserta didik, antara peserta didik dengan pendidik dan sumber belajar lainnya pada suatu lingkungan belajar untuk mencapai penguasaan kompetensi yang ditetapkan (permendikbud no. 34 tahun 2018).

Untuk mencapai tujuan tersebut tentunya tidak terlepas dari proses pembelajaran yang memerlukan metode dan strategi yang benar, tepat dan bermakna agar memperoleh hasil yang maksimal sesuai dengan tahapan kompetensi yang harus dicapai siswa.

Teknik Komputer dan Jaringan (TKJ) adalah salah satu program keahlian di Sekolah Menengah Kejuruan (SMK) yang bertujuan membekali peserta didik dengan keterampilan, pengetahuan, dan sikap agar kompeten dalam merakit, menginstal program, merawat dan memperbaiki komputer serta jaringannya.

Melakukan instalasi sistem operasi jaringan merupakan salah satu kompetensi pada mata pelajaran Administrasi Sistem Jaringan (ASJ) yang harus dikuasai oleh siswa progam keahlian TKJ. Keterampilan dan ketelitian siswa sangat diperlukan dalam melakukan instalasi sistem operasi jaringan baik yang berbasis GUI (Graphical User Interface) maupun CLI (Command Linte Interface). Oleh karena itu, siswa dituntut harus memiliki motivasi belajar yang tinggi agar mampu dan terampil dalam setiap temuan dan pemecahan masalah yang berhubungan dengan sistem operasi jaringan Berdasarkan pengamatan terhadap siswa kelas XI TKJ SMK Negeri 1 Sigli diperoleh bahwa siswa yang mampu menginstal sistem operasi jaringan dengan benar sangat rendah terutama pada system operasi yang berbasis tekt. Dari 28 siswa ternyata hanya 13 siswa yang mampu dan dapat dikatakan tuntas dengan nilai KKM=75. Dari hasil pengamatan situasi proses pembelajaran instalasi sistem operasi jaringan ditemukan beberapa siswa kurang serius dalam melaksanakannya bahkan ada yang merasa jenuh. Beberapa faktor yang menjadi alasan kejenuhan mereka yaitu pada saat mengintalasi Sistem Operasi Jaringan, waktu yang dibutuhkan sangat lama mulai dari menyiapkan software, menginstal sampai melakukan pengujian hasil instalasi. Dalam proses tahapan penyelesaian instalasi yang cenderung lama dan beberapa proses pengetikan sintak yang kurang teliti dan salah sehingga memberi kesan yang membosankan bagi siswa dan meninggalkannya begitu saja, mereka mengisi waktu dengan berbagai kegiatan lain yang tidak linear dengan kegiatan mata pelajaran ASJ. Terkadang guru harus menegur siswa karena aktivitasnya dalam kelas yang mengganggu proses pembelajaran. Bahkan yang paling memprihatinkan motivasi siswa dalam mengikuti pelajaran pada materi Sistem Operasi Jaringan berkurang sehingga berpengaruh pada nilai akhir siswa.

Dalam hal ini perlu adanya peningkatan motivasi siswa dalam belajar karena menurut Kompri (2016:233) Kedudukan motivasi dalam belajar tidak hanya memberikan arah kegiatan belajar secara benar, lebih dari itu dengan motivasi seseorang akan mendapat pertimbanganpertimbangan positif dalam kegiatan belajar

Hasil asumsi bahwa rendahnya motivasi belajar siswa tersebut disebabkan penggunaan metode yang tidak tepat, serta karakteristik materi Sistem Operasi Jaringan yang menghabiskan waktu lama sementara siswa ingin cepat selesai dan terus melanjutkan ke tindakan selanjutnya mencari dan mencoba sesuatu yang baru. Siswa ingin berbuat sesuatu dan bertindak lebih jauh tanpa dibatasi oleh model dan cara yang benar.

Berdasarkan temuan dan karakteristik tersebut, alternatif pemecahannya dengan cara melibatkan siswa secara aktif dalam 
menerapkan suatu metode pembelajaran yang diharapkan dapat mengatasi rendahnya motivasi belajar siswa Teknik Komputer dan jaringan (TKJ) kelas XI TKJ melalui metode discovery learning menggunakan pendekatan saintifik. Metode pembelajaran ini dipilih karena dengan menemukan sendiri, menyelidiki sendiri, maka hasil yang diperoleh akan setia dan tahan lama dalam ingatan, tidak akan mudah dilupakan siswa. Dengan belajar penemuan, anak juga bisa belajar berpikir analisis dan mencoba memecahkan sendiri problem yang dihadapi. Kebiasaan ini akan ditransfer dalam kehidupan berasyarakat (Hosnan, 2014: 282). Dalam metode pembelajaran discovery siswa lebih aktif dalam memecahkan masalah untuk menemukan sedang guru berperan sebagai pembimbing atau memberikan petunjuk cara memecahkan masalah itu.

Penelitian tindakan kelas ini bertujuan untuk meningkatkan motivasi dan kemampuan siswa mengintalasi Sistem Operasi Jaringan dengan metode discovery learning di Kelas XI TKJ SMKN 1 Sigli tahun pelajaran 2019/2020.

\section{METODE PENELITIAN}

Penelitian ini merupakan penelitian tindakan kelas (PTK). Penelitian Tindakan kelas adalah suatu pendekatan untuk memperbaiki pendidikan melalui perubahan, dengan mendorong para guru untuk memikirkan praktik mengajarnya sendiri, agar kritis terhadap praktik tersebut dan agar mau untuk mengubahnya. PTK mendorong guru untuk berani bertindak dan berpikir kritis dalam mengembangkan teori.

dan rasional bagi mereka sendiri, dan bertanggung jawab mengenai pelaksanaan tugasnya secara profesional (Hardjodipuro, 2014:20). Dalam penelitian ini mengembangkan siklus yang mengandung empat komponen yaitu: rencana tindakan (planning), (2) pelaksanaan (action), observasi (observation), (4) refleksi (reflection).

Penelitian dilaksanakan di SMKN 1 Sigli pada Program Keahlian Teknik Komputer dan Jaringan pada saat jam pelajaran Administrasi Sistem Jaringan. Sebagai subjek dalam penelitian ini adalah siswa kelas XI TKJ tahun pelajaran 2019/2020 dengan jumlah siswa sebanyak 28 orang.

Dalam melaksanakan tindakan pada tiap siklus, penulis membuat rekayasa masalah dengan mensetting komputer sehingga tidak dapat digunakan karena Sistem Operasi Jaringannya rusak. Siswa diminta untuk melakukan perbaikan dengan cara menginstal ulang Sistem Operasi Jaringan sampai komputer tersebut dapat berfungsi kembali dengan normal.

Teknik pengumpulan data dilakukan dengan cara observasi, tes dan dokumentasi. Observasi kegiatan guru dipandu dengan lembar pengamatan yang dilakukan dengan bantuan teman sejawat. Tes diberikan setelah mendapat perlakuan untuk mengetahui sejauh mana tingkat ketuntasan belajar siswa terhadap materi yang disampaikan melalui model pembelajaran Discovery dengan pendekatan saintifik,

Analisis data yang digunakan adalah analisis deskriptif kualitatif. Data yang dianalisis ini adalah nilai tes tertulis dan praktik Menginstalasi Sistem Operasi Jaringan“. Analisis data yang dipergunakan adalah sebagai berikut :

Secara individual, siswa telah tuntas belajar jika mencapai skor $75 \%$ atau nilai 75 dengan perhitungan sebagai berikut:

$$
\text { Skor Siswa }=\frac{\text { Skoryangdiperoleh }}{\text { Skormaksim um }} \times 100 \%
$$

Suatu kelas dinyatkan tuntas belajar jika terdapat $\geq 85 \%$ dari jumlah siswa telah tuntas belajar. Perhitungan untuk menyatakan ketuntasan belajar siswa secara klasikal dengan menggunakan rumus persentase, yaitu:

$$
\mathrm{P}=\frac{\text { jumlahsiswayangtuntas }}{\text { jumlahsiswakeseluruahan }} \times 100 \%
$$


Jurnal Sosial Humaniora Sigli (JSH)

p ISSN : 2615-3688

$e$ ISSN : 2716-0270

http://journal.unigha.ac.id/index.php/JSH

\section{HASIL PEMBAHASAN}

Pada Siklus I Pertemuan pertama dilaksanakan pada tanggal 22 Juli 2019, hari senin jam pelajaran ke-1 sampai ke-6. Langkah-langkah pembelajaran dimulai dari Pre Activities; yaitu guru memasuki kelas dan mengucapkan salam setelah itu bersama-sama dengan siswa membaca doa, guru mengabsen kehadiran siswa. Setelah itu guru menjelaskan tujuan pembelajaran dan teknis belajar.

Materinya adalah Sistem Operasi Jaringan. Tujuan dari pembelajaran ini adalah diharapkan siswa mampu mengindentifikasi kerusakan pada Sistem Operasi Jaringan dan penyebab kerusakan tersebut.

Materi pembelajaran permasalahan yang terjadi pada Sistem Operasi Jaringan komputer Sedangkan metode pembelajaran menggunakan penerapan pendekatan saintifik dengan model pembelajaran discovery learning.Pada kegiatan inti guru merekayasa masalah dengan menghapus Sistem Operasi Jaringan pada sebuah PC yang biasa digunakan sebagai salah satu server di Laboratorium TKJ dan meminta siswa untuk mengamati komputer tersebut. Guru memberikan pertanyaan kepada siswa tentang kasus rekayasa tersebut. Selanjutnya guru memberi penjelasan kepada siswa dan pada akhir kegiatan guru menyimpulkan materi yang telah disajikan dan memberikan kesempatan untuk bertanya. Guru meminta siswa mencari informasi melalui Labtop mereka masing-masing yang terhubung dengan wifi lab TKJ untuk memecahkan masalah yang telah direkayasa tersebut.

Pertemuan kedua dilaksanakan pada tanggal 29 Juli 2019, hari senin, jam pelajaran ke-1 sampai ke-6. Langkahlangkah pembelajaran dimulai dari Pre activities; yaitu guru memasuki kelas dan mengucapkan salam setelah itu bersamasama dengan siswa membaca doa, guru mengabsen kehadiran siswa. Selanjutnya guru menjelaskan tujuan pembelajaran dan teknis belajar. Tujuan dari pembelajaran ini adalah diharapkan siswa dapat memahami penyebab dari kerusakan Sistem Operasi Jaringan dan cara mengatasinya. Materi pembelajaran penyebab kerusakan Sistem Operasi Jaringan Linux. Pada kegiatan inti Guru menjelaskan beberapa kasus kerusakan Sistem Operasi Jaringan Linux dan cara mengidentifikasi kerusakannya. Pada akhir kegiatan, guru memberikan tugas kepada siswa untuk mencari informasi tentang materi yang telah diberikan di internet sebagai materi tambahan.

Dalam pelaksanaannya siswa dibagi menjadi 6 kelompok dimana setiap kelompok terdiri dari 5 sampai enam orang siswa. Guru memberikan tugas kepada masing masing kelompok untuk membuat paper/makalah tentang langkah-langkah instalasi Sistem Operasi Jaringan Linux serta menyimpulkan materi pembelajaran.

Pertemuan ketiga dilaksanakan pada tanggal 5 Agustus 2019, hari Senin, jam pelajaran ke-1 dan 6. Kompetensi dasarnya sama dengan pertemuan 1 dan ke 2 dengan indikator siswa memahami Prosedur instalasi Sistem Operasi Jaringan. Langkahlangkah pembelajaran dimulai dari Pre activities; guru memasuki kelas dan mengucapkan salam setelah itu bersamasama dengan siswa membaca doa, guru mengabsen kehadiran siswa. Setelah itu guru menjelaskan tujuan pembelajaran dan teknis belajar. Tujuan dari pembelajaran ini adalah diharapkan siswa dapat memahami prosedur instalasi Sistem Operasi Jaringan. Pada kegiatan inti; Siswa diminta untuk menonton tayangan cara menginstalasi Sistem Operasi Jaringan Linux. Selama tayangan guru memberikan penekanan halhal yang penting dalam pelaksanaan instalasi Sistem Operasi Jaringan Linux.

Berdasarkan hasil pelaksanaan selama siklus I, diperoleh nilai rata-rata skor hasil observasi terhadap motivasi belajar siswa adalah 21, yang merupakan jumlah skor tersebut termasuk dalam kategori kurang berminat. Sementara hasil tes akhir siklus I bahwa ada 11 siswa yang tidak tuntas belajar. Siswa yang tidak tuntas sudah 
Jurnal Sosial Humaniora Sigli (JSH)

p ISSN : 2615-3688

$e$ ISSN : 2716-0270

http://journal.unigha.ac.id/index.php/JSH

mengikuti program remedial berupa pemberian tugas secara mandiri dan diakhiri dengan test. Adapun hasil test belajar siswa pada siklus I dapat dilihat pada grafik di bawah ini,

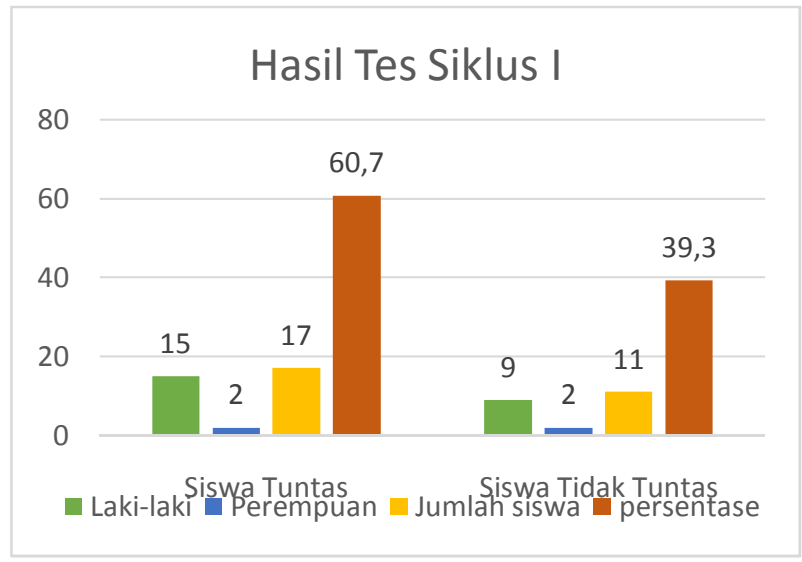

Analisis data hasil tes akhir siklus I menggunakan Kriteria Ketuntasan Minimal (KKM) sebesar 39,3\% siswa yang belum mencapai KKM harus mengikuti program perbaikan (remedial). 60,7\% siswa yang sudah mencapai atau melampaui KKM dan dianggap tuntas dan diberikan program lanjutan. Selanjutnya hasil siklus I akan diperbaiki pada pelaksanaan kegiatan pembelajaran pada siklus II.

Hasil pengamatan selama siklus II, diperoleh data sebagai berikut. Selama pembelajaran rata-rata skor hasil observasi terhadap aktivitas belajar siswa. diperoleh nilai rata-rata skor hasil observasi terhadap motivasi belajar siswa adalah 28 , yang merupakan jumlah skor tersebut termasuk dalam interval kategori berminat. Selanjutnya dari hasil tes akhir pada siklus II menunjukkan bahwa hampir semua siswa memperoleh nilai ketuntasan dalam belajar. Hanya 1 orang siswa yang belum tuntas. Adapun hasil test belajar siswa pada siklus II dapat dilihat pada grafik di samping ini,

Analisis data hasil tes akhir siklus II menggunakan Kriteria Ketuntasan Minimal (KKM) sebesar 96,4\% Siswa sudah mencapai atau melampaui KKM dan selanjutnya akan diberikan program lanjutan. sisanya $3,6 \%$ yang belum tuntas dan akan diberikan program remedial sampai tuntas.

Disini dapat dilihat bahwa dengan perlakuan pada siklus kedua sudah hampir mencapai $100 \%$ yaitu $96,4 \%$ siswa yang

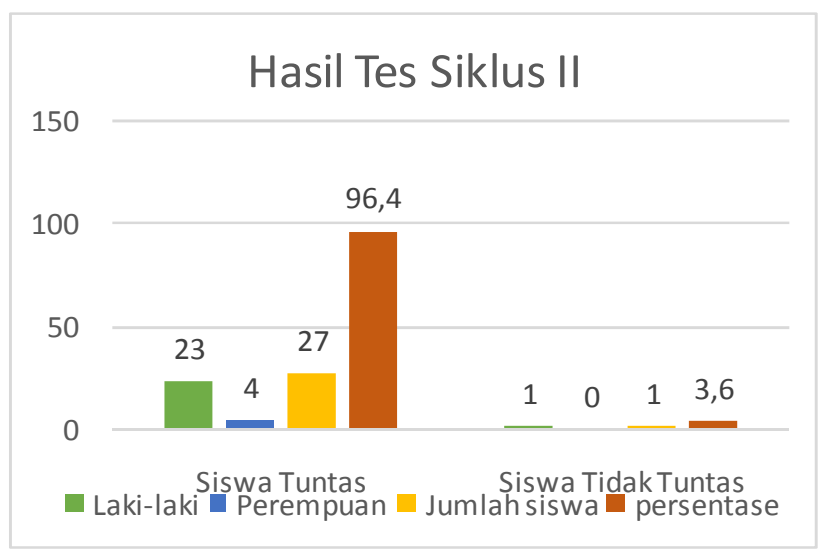

sudah melampaui KKM. Ini artinya secara keseluruhan kemampuan siswa dalam menginstalasi Sistem Operasi Jaringan sudah sangat meningkat.

\section{KESIMPULAN}

Berdasarkan hasil penelitian dapat disimpulkan bahwa pembelajaran melalui metode discovery learning dengan menggunakan pendekatan saintifik dapat meningkatkan motivasi dan kemampuan dalam menginstalasi sistem operasi jaringan pada siswa kelas XI TKJ SMK Negeri 1 Sigli.

Merujuk pada hasil penelitian yang diperoleh maka penulis dapat menyarankan sebagai berikut: bagi guru jangan pernah berhenti untuk mencoba dan memilih metode pembelajaran yang tepat bagi siswa agar dapat meningkatkan motivasi belajar siswa sehingga materi pembelajaran dapat terserap dengan baik oleh siswa. Bagi peneliti lain, agar dapat menjadikan hasil penelitian ini sebagai informasi dan tambahan referensi bagi penelitian selanjutnya.

\section{DAFTAR PUSTAKA}

Cahyo, Agus. 2013. Panduan Aplikasi Teori-teori Belajar Mengajar. Jogjakarta: DIVA press 
Djamarah. 2011. Psikologi Belajar. Jakarta : Rineka Cipta

(Diakses: 28 Oktober 2019 pukul 10:15 wib)

Eggen. 2012. Strategi dan Model

Pembelajaran, Jakarta : PT.Indeks

Hardjodipuro. 2014. Penelitian Tindakan Kelas. Jakarta: Depdiknas.

Hosnan, M. 2014. Pendekatan Saintifik dan Kontekstual dalam Pembelajaran Abad 21: Kunci Sukses Implementasi Kurikulum 2013. Jakarta. Ghalia Indonesia

Kompri. (2016). Motivasi Pembelajaran Perspektif Guru dan Siswa. Bandung: PT. Rosda Karya.

Listika Burais, dkk. 2016. Peningkatan Kemampuan Penalaran Matematis Siswa Melalui Model Discovery Learning. Dalam Jurnal Didaktik Matematika ISSN: 2355-4185 77,Vol. 3, No.1, Tahun 2016, pp 80

Robbin (2007). Prilaku Organisasi. Yogyakarta: Pustaka Pelajar

Rusman .2015. Pembelajaran Tematik Terpadu, Jakarata: PT Raja Grafindo Persada

Sagita, M., \& Khairunnisa, K. (2020). ELearning for Educators in Digital Era 4.0. Budapest International Research and Critics Institute (BIRCI-Journal): Humanities and Social Sciences, 3(2), 1297-1302.

Takdir, MI. 2012. Pembelajaran Discovery Strategy \& Mental Vocational Skill. Jogjakarta: DIVA Press

Yusdi, Milman. 2010. Pengertian Kemampuan. blogspot.com/ pengertian kemampuan. html. 